\title{
Article
}

\section{Degradation of Oxytetracycline by Persulfate Activation Using a Magnetic Separable Iron Oxide Catalyst Derived from Hand-Warmer Waste}

\author{
Youn-Jun Lee ${ }^{1}$, Chang-Gu Lee ${ }^{1, *}$, Seong-Jik Park ${ }^{2}(\mathbb{D})$ and Eun Hea Jho ${ }^{3, *(D)}$ \\ 1 Department of Environmental and Safety Engineering, Ajou University, Suwon 16499, Korea; \\ duswnss@ajou.ac.kr \\ 2 Department of Bioresources and Rural Systems Engineering, Hankyong National University, \\ Anseong 17579, Korea; parkseongjik@hknu.ac.kr \\ 3 Department of Agricultural and Biological Chemistry, Chonnam National University, Gwangju 61186, Korea \\ * Correspondence: changgu@ajou.ac.kr (C.-G.L.); ejho001@chonnam.ac.kr (E.H.J.); \\ Tel.: +82-31-219-2405 (C.-G.L.); +82-62-530-2134 (E.H.J.)
}

Citation: Lee, Y.-J.; Lee, C.-G.; Park,

S.-J.; Jho, E.H. Degradation of

Oxytetracycline by Persulfate

Activation Using a Magnetic

Separable Iron Oxide Catalyst

Derived from Hand-Warmer Waste.

Appl. Sci. 2021, 11, 10447. https://

doi.org/10.3390/app112110447

Academic Editor: Rajender S. Varma

Received: 4 October 2021

Accepted: 5 November 2021

Published: 7 November 2021

Publisher's Note: MDPI stays neutral with regard to jurisdictional claims in published maps and institutional affiliations.

Copyright: (c) 2021 by the authors. Licensee MDPI, Basel, Switzerland. This article is an open access article distributed under the terms and conditions of the Creative Commons Attribution (CC BY) license (https:// creativecommons.org/licenses/by/ $4.0 /)$.

\begin{abstract}
Oxytetracycline (OTC) is a tetracycline antibiotic that is widely used in the drug therapy and livestock industry and may threaten human health and ecosystems when released into the environment. In this study, a catalyst was prepared from hand-warmer waste using a simple magnetic separation method. The prepared hand-warmer waste catalyst (HWWC) was used as a persulfate (PS) activator for OTC removal. Characterization methods, such as X-ray diffraction and scanning electron microscopy-energy dispersive $\mathrm{X}$-ray spectrometry, were used to investigate the crystal structure, surface morphology, and weight ratios of the elements in the HWWC. The degradation efficiency of OTC in the presence of the catalyst and PS was studied, and the radical generation mechanism of the catalyst was investigated. The removal ratio of OTC by PS activation was greater than $99 \%$ for a reaction time of $24 \mathrm{~min}$ at a $\mathrm{pH}$ of 6 . The effects of the HWWC dosage, PS concentration, and solution $\mathrm{pH}$ on OTC degradation were also investigated. The reuse test revealed that HWWC can be reused for eight cycles with great stability. These results suggest that PS activation using hand-warmer waste can be an efficient strategy for the degradation of antibiotics.
\end{abstract}

Keywords: antibiotics; persulfate activation; hand-warmer waste; magnetic separable iron oxide catalyst; Fenton-like reaction

\section{Introduction}

The amount of antibiotics released into the environment is increasing owing to the lack of appropriate disposal methods and strict control measures, which threaten human health and the ecosystem [1,2]. Oxytetracycline (OTC), an antibiotic, is widely used as an antimicrobial agent and growth factor in drug therapy and the livestock industry $[3,4]$. Approximately 70\% of OTC leaves organisms via urine and feces without undergoing metabolism because of its poor absorption [5]. Therefore, OTC has been detected in various environments, such as aquatic systems, soil, and sediments [6-8]. In aquatic environments, several studies have reported that OTC has been detected in river water [9] and in the influent and effluent of a wastewater treatment plant [10-13]. However, it is difficult to degrade the released OTC in water using conventional wastewater treatment processes [14]. Therefore, effective treatment of OTC in water is a problem that needs to be solved urgently.

Sulfate radicals $\left(\mathrm{SO}_{4} \bullet^{-}\right)$and hydroxyl radicals ( $\mathrm{HO} \bullet$ ) are widely used reactive radical species in wastewater treatment because of their high oxidizing capabilities [15]. Generally, activating peroxides such as persulfate (PS), peroxymonosulfate, and hydrogen peroxide or photocatalytic processes can generate these radical species [16]. Among the abovementioned peroxides, PS is much cheaper and easier to activate owing to its low band energy $(140 \mathrm{~kJ} / \mathrm{mol})[17,18]$, PS has attracted attention as an oxidant for degrading various 
pollutants $[19,20]$. Catalysts such as metal-containing oxides and transition metals have been used to activate PS because they are energy-free and economic [21-23]. Moreover, research on the reuse of waste containing metal elements such as Fe as a PS activator has been conducted $[16,24,25]$.

Disposable hand warmers are widely used to keep oneself warm; thus, the demand for hand warmers greatly increases in winter. After exposure to air, the materials in the hand warmer pocket react and release heat for a period of time. The spent hand warmer is then discarded, which can adversely affect the environment and lead to wastage of resources [26], recycling or reusing the spent hand warmer is needed to reduce environmental pollution. Hand-warmer waste generally contains iron oxide $\left(\mathrm{Fe}_{2} \mathrm{O}_{3}\right)$ particles. Therefore, reusing hand-warmer waste for the activation of PS can be an environmentally friendly and cost-saving technique. To the best of our knowledge, this study is the first to recycle hand-warmer waste as a catalyst for PS activation.

In this study, a hand-warmer waste catalyst (HWWC) was prepared by a simple magnetic separation method and used as a PS activator for OTC degradation. The surface morphology and crystal structure of the prepared HWWC were investigated. The effects of the catalyst dosage, PS concentration, and $\mathrm{pH}$ on the degradation of OTC were studied. In addition, the stability of the catalyst was evaluated by conducting a reuse test.

\section{Materials and Methods}

\subsection{Chemical and Materials}

A hand warmer was obtained from DABONG Industrial Co., Ltd. (Seoul, Korea). Oxytetracycline hydrochloride $\left(\mathrm{C}_{22} \mathrm{H}_{24} \mathrm{~N}_{2} \mathrm{O}_{9} \cdot \mathrm{HCl} \geq 97.5 \%\right)$ was purchased from SigmaAldrich Co., Ltd. (Burlington, MA, USA). Sodium phosphate monobasic anhydrous $\left(\mathrm{NaH}_{2} \mathrm{PO}_{4} \geq 98 \%\right)$, sodium phosphate dibasic anhydrous $\left(\mathrm{Na}_{2} \mathrm{HPO}_{4} \geq 99.0 \%\right)$, sodium hydroxide $(\mathrm{NaOH} \geq 98.0 \%)$, hydrogen chloride $(\mathrm{HCl} \geq 35.0-37.0 \%)$, and acetonitrile (ACN) $\left(\mathrm{CH}_{3} \mathrm{CN} \geq 99.9 \%\right)$ were purchased from Samchun Pure Chemical Co., Ltd. (Pyeongtaek-si, Korea). Sodium persulfate $\left(\mathrm{Na}_{2} \mathrm{~S}_{2} \mathrm{O}_{8} \geq 98 \%\right)$ was purchased from Junsei Chemical Co., Ltd. (Tokyo, Japan). Deionized (DI) water with a resistivity of $18.2 \mathrm{M} \Omega / \mathrm{cm}$ (Millipore, Darmstadt, Germany) was used to prepare the solutions.

\subsection{Catalyst Preparation}

HWWC was prepared using a simple magnetic separation method. After a disposable hand warmer was exposed to air for $36 \mathrm{~h}, 10 \mathrm{~g}$ of the contents inside the hand warmer were placed in $1 \mathrm{~L}$ of DI water. The $\mathrm{Fe}_{2} \mathrm{O}_{3}$ in the DI water was then magnetically separated. The separation process was repeated three times, and the obtained solid was dried in an oven at $80{ }^{\circ} \mathrm{C}$ for $24 \mathrm{~h}$. The dried solid was ground for further experiments.

\subsection{Experimental Procedure}

The OTC degradation experiments were initiated by adding $1 \mathrm{mM}$ PS to $50 \mathrm{~mL}$ of the solution containing $20 \mu \mathrm{M}$ OTC and $0.2 \mathrm{~g} / \mathrm{L}$ HWWC. The reaction was conducted in a shaking incubator at $150 \mathrm{rpm}$ and $25^{\circ} \mathrm{C}$. The $\mathrm{pH}$ of the solution was adjusted to $3,4,6$, and 8 using $0.1 \mathrm{M} \mathrm{NaOH}$ and $0.1 \mathrm{M} \mathrm{HCl}$ and analyzed using a $\mathrm{pH}$ meter (Orion Star A211, Thermo, Waltham, MA, USA). To perform the reuse test, the catalyst was magnetically separated after each reaction cycle.

\subsection{Analytical Method}

The OTC concentration was measured using a YL 9100 HPLC system (Youngin Chromass, Anyang, Korea) with a YL 9120 UV/Vis detector and YL 9150 autosampler. A YL C18-4D column $(4.6 \mathrm{~mm} \times 150 \mathrm{~mm}, 5 \mu \mathrm{m})$ was used to separate methanol, ACN, and $10 \mathrm{mM}$ phosphate buffer ( $\mathrm{pH}$ of 7) (15:15:70). The mobile phase was isocratically eluted at a flow rate of $1.0 \mathrm{~mL} / \mathrm{min}$. The column temperature was $35^{\circ} \mathrm{C}$, and OTC was detected at $260 \mathrm{~nm}$. 


\subsection{Characterization}

The surface morphology and elemental contents of the HWWC were observed using a scanning electron microscope-energy dispersive X-ray spectrometer (SEM-EDS) (JSM-7900F, JEOL, Tokyo, Japan). The X-ray diffraction (XRD) pattern of the catalyst was analyzed using an XRD system (D/max-2500V, Rigaku, Tokyo, Japan). The point of zero charge $\left(\mathrm{pH}_{\mathrm{pzc}}\right)$ of HWWC was determined by titration method with slight modification [27]. HWWC (0.04 g) was suspended in $20 \mathrm{~mL}$ of $0.01 \mathrm{M} \mathrm{NaNO}_{3}$ for $24 \mathrm{~h}$. Then the $\mathrm{pH}$ of solution was adjusted using $0.1 \mathrm{M} \mathrm{HNO}_{3}$ or $\mathrm{NaOH}$ solution. To reach the equilibrium, the solution was agitated for $1 \mathrm{~h}$, then the $\mathrm{pH}_{\text {initial }}$ was measured. After measuring the $\mathrm{pH}_{\text {initial }}, 0.6 \mathrm{~g}$ of $\mathrm{NaNO}_{3}$ was added to the suspension. After $3 \mathrm{~h}$, the $\mathrm{pH}_{\text {final }}$ of the solution was measured. The $\mathrm{pH}_{\mathrm{pzc}}$ value was determined as $\Delta \mathrm{pH}\left(\mathrm{pH}_{\text {final }}-\mathrm{pH}_{\text {initial }}\right)$ was 0 when plotting $\Delta \mathrm{pH}$ against $\mathrm{pH}_{\text {final }}$. As shown in Figure $1 \mathrm{a}, \mathrm{pH}_{\mathrm{pzc}}$ of $\mathrm{HWWC}$ was 7.4. The magnetic property of HWWC was measured using vibrating sample magnetometer (VSM) (Model 7404, Lake shore cryotronics, Westerville, OH, USA).
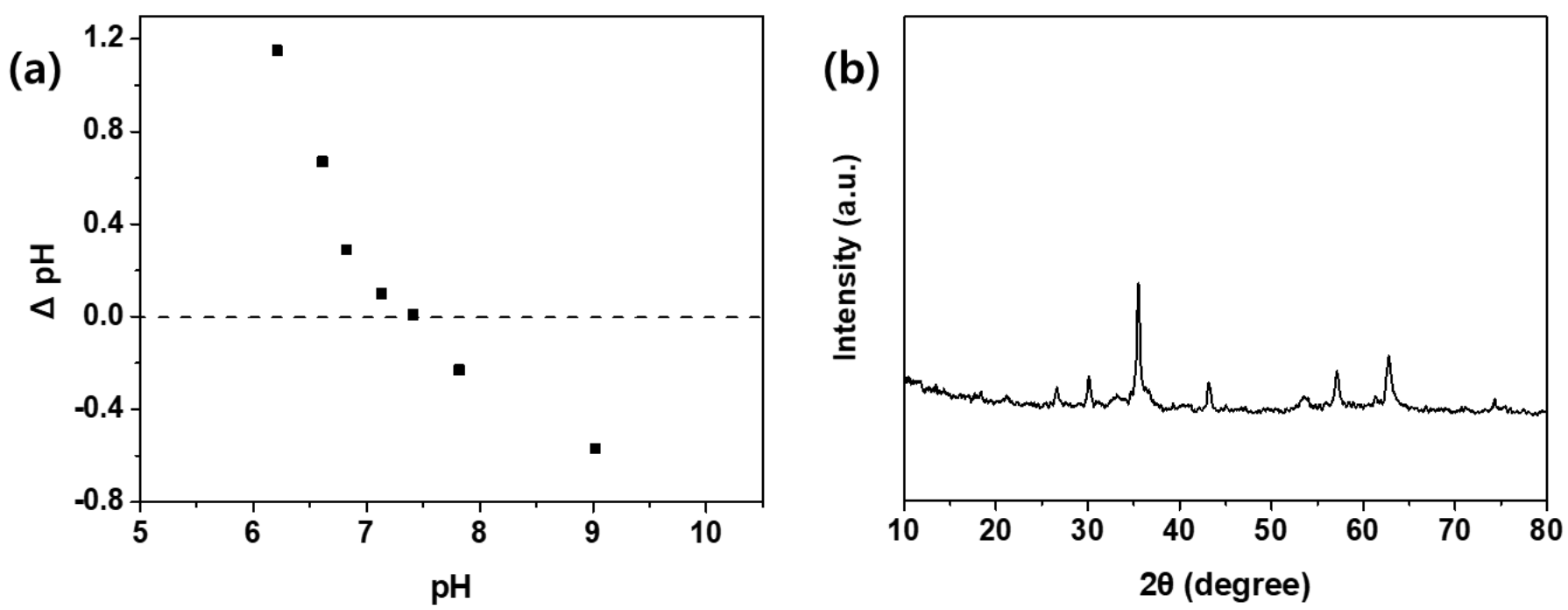

Figure 1. (a) $\mathrm{pH}_{\mathrm{pzc}}$ measurement and (b) X-ray diffraction pattern of prepared hand-warmer waste catalyst.

\section{Results and Discussion}

\subsection{Crystal Structure, Surface Morphology, and Magnetic Properties of HWWC}

Figure $1 \mathrm{~b}$ shows the XRD patterns of the prepared HWWC. The strongest peak observed at approximately $2 \theta=35.58^{\circ}$ indicated a reduction in the (119) diffraction of $\gamma$ $\mathrm{Fe}_{2} \mathrm{O}_{3}$ [28]. The peaks observed at approximately $30.08^{\circ}, 43.16^{\circ}, 57.16^{\circ}$, and $62.80^{\circ}$ corresponding to (205), (0012), (1115), and (4012) were also in good agreement with those of $\gamma-\mathrm{Fe}_{2} \mathrm{O}_{3}[28,29]$. Other impurity peaks at approximately $33.30^{\circ}, 54.10^{\circ}$, and $63.40^{\circ}$ agreed with $\alpha-\mathrm{Fe}_{2} \mathrm{O}_{3}$ [30]. These results indicated that the magnetically separated HWWC was a mixture mainly consisting of $\gamma-\mathrm{Fe}_{2} \mathrm{O}_{3}$ and $\alpha-\mathrm{Fe}_{2} \mathrm{O}$.

Figure 2 shows the SEM images and EDS spectra of the HWWC particles. The morphology of the particles was approximately spherical (Figure 2a). Based on the elemental analysis $(\mathrm{O}=32.23 \%, \mathrm{Fe}=66.98 \%$ ) (Figure $2 \mathrm{~b})$, it was determined that the sample mainly consisted of $\mathrm{Fe}$ and $\mathrm{O}$, therefore confirming that the produced powder was $\mathrm{Fe}_{2} \mathrm{O}_{3}$, which agreed with the XRD results.

Figure 3 shows the VSM analysis result of the HWWC particles. The saturation magnetization of the HWWC was determined to be $34.14 \mathrm{emu} / \mathrm{g}$, which was sufficient $(>16.3 \mathrm{emu} / \mathrm{g})$ for it to be magnetically recovered from solution using a conventional magnet [31,32]. Thus, HWWC can be easily recovered from water through magnetic separation and reused. 


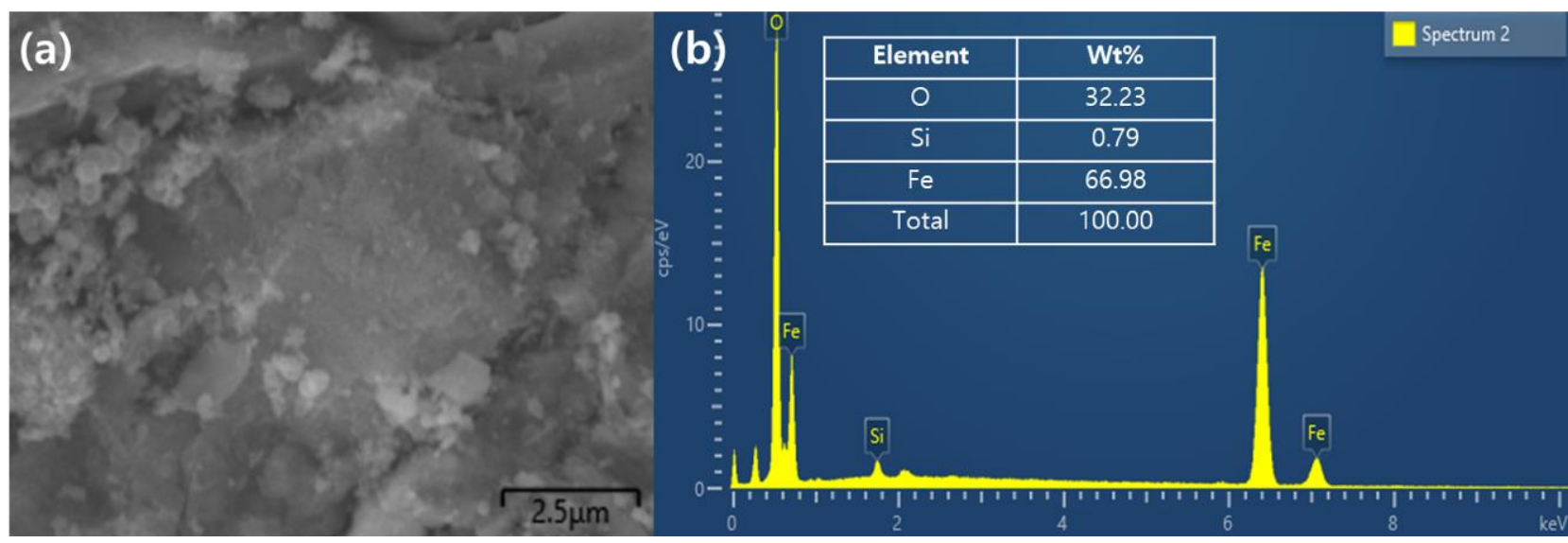

Figure 2. (a) Scanning electron microscope image and (b) energy dispersive X-ray spectrometer result of the prepared hand-warmer waste catalyst.

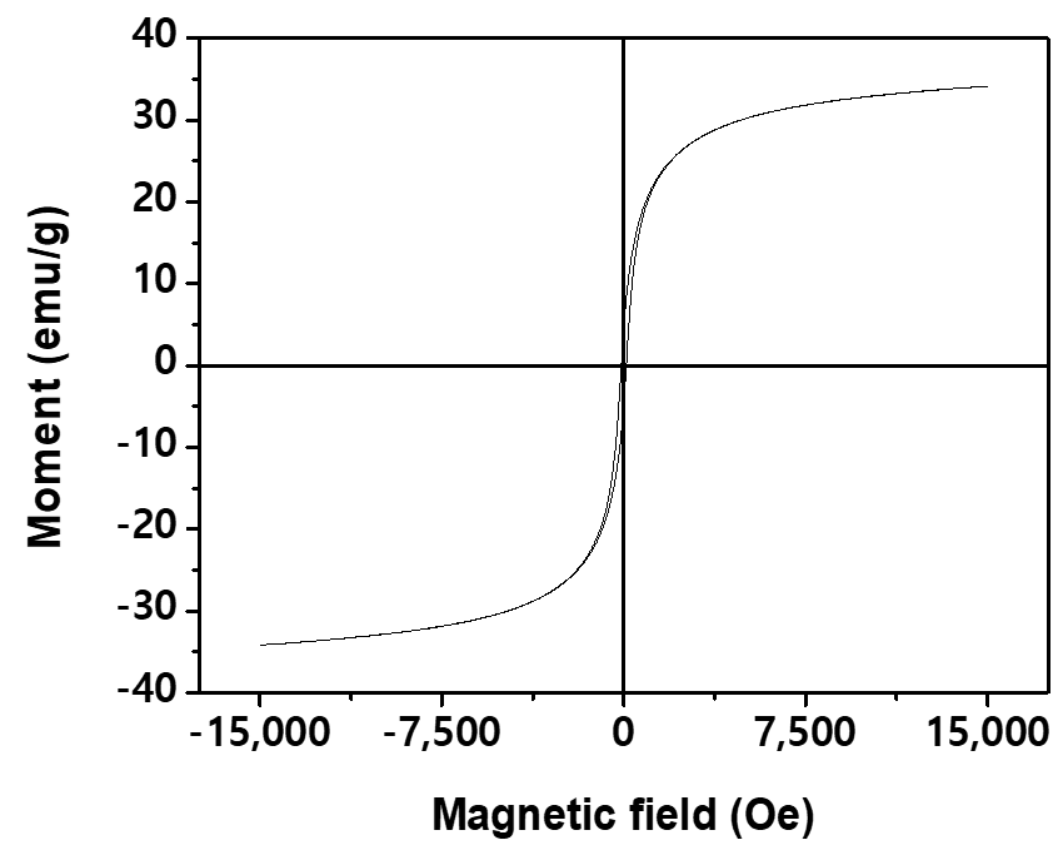

Figure 3. Vibrating sample magnetometer (VSM) analysis result of HWWC.

\subsection{Control Experiments}

Figure 4 shows the removal of OTC under different experimental conditions. OTC was removed when both PS and HWWC were present. The degradation efficiency of OTC by PS activation was greater than $99 \%$ in $24 \mathrm{~min}$, and the estimated pseudo firstorder rate constant $(\mathrm{k})$ was $0.21 \pm 0.03 \mathrm{~min}^{-1}$. This removal rate was comparable to OTC degradation through the Fenton process using $\mathrm{H}_{2} \mathrm{O}_{2} / \mathrm{Fe}^{2+}\left(\mathrm{k}_{\mathrm{app}}=0.068-0.213 \mathrm{~min}^{-1}\right)$ [33], which indicates that the PS activation process using HWWC can be a promising technique for removing antibiotics from water. The removal rate of OTC in the presence of PS and HWWC in 24 min was low $(<6.0 \%)$. The degradation mechanism of OTC by PS activation can be expressed by the following equations (Equations (1)-(5)) [34]:

$$
\begin{gathered}
\text { Pollutant }+\mathrm{Fe}(\mathrm{III}) \rightarrow \text { Pollutant }+\mathrm{Fe}(\mathrm{II}) \\
\mathrm{Fe}(\mathrm{II})+\mathrm{S}_{2} \mathrm{O}_{8}{ }^{2-} \rightarrow \mathrm{Fe}(\mathrm{III})+\mathrm{SO}_{4}{ }^{\bullet-}+\mathrm{SO}_{4}{ }^{2-} \\
\mathrm{Fe}(\mathrm{III})+\mathrm{H}_{2} \mathrm{O} \rightarrow \mathrm{Fe}(\mathrm{II})+\mathrm{HO}^{\bullet}+\mathrm{H}^{+} \\
\mathrm{H}_{2} \mathrm{O}+\mathrm{SO}_{4}{ }^{\bullet-} \rightarrow \mathrm{H}^{+}+\mathrm{HO}^{\bullet}+\mathrm{SO}_{4}{ }^{2-}
\end{gathered}
$$




$$
\mathrm{SO}_{4}^{\bullet-}+\mathrm{HO}^{\bullet}+\text { Pollutant } \rightarrow \mathrm{CO}_{2}+\mathrm{H}_{2} \mathrm{O}
$$

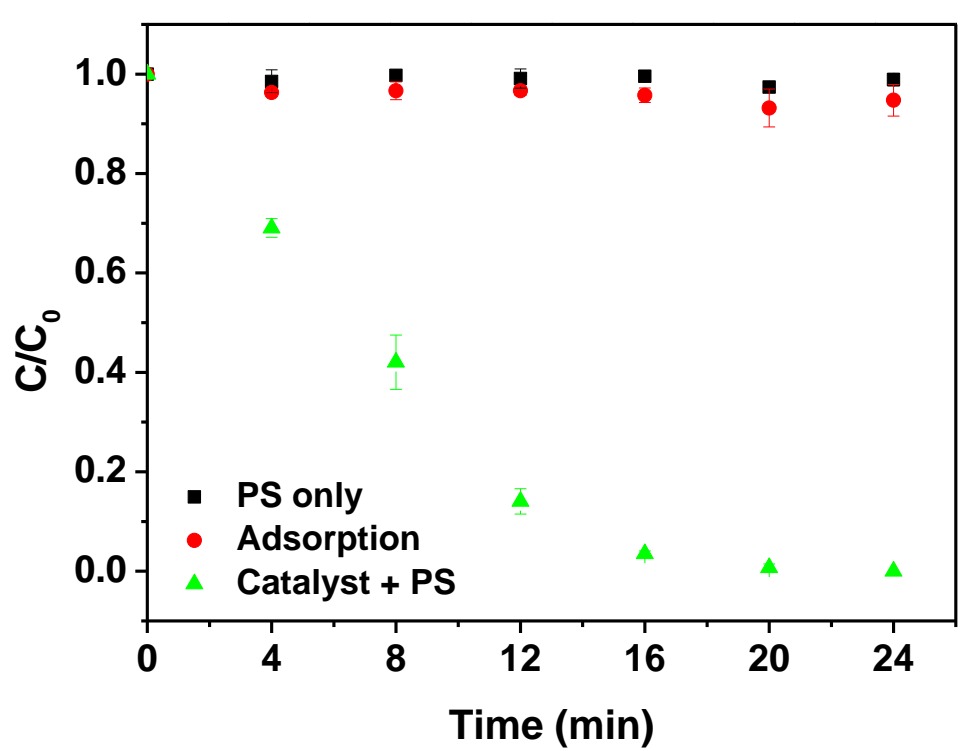

Figure 4. Control experiment for oxytetracycline (OTC) degradation $\left([\mathrm{PS}]_{0}=1 \mathrm{mM},[\mathrm{OTC}]_{0}=20 \mu \mathrm{M}\right.$, $\left.[\mathrm{HWWC}]_{0}=0.2 \mathrm{~g} / \mathrm{L}, \mathrm{pH}=6\right)$. PS: persulfate; HWWC: hand-warmer waste catalyst.

The electrons could be transferred to Fe(III) when the pollutant was adsorbed onto the $\mathrm{Fe}_{2} \mathrm{O}_{3}$ surface (Equation (1)). Therefore, a Fenton-like reaction occurred between $\mathrm{S}_{2} \mathrm{O}_{8}{ }^{2-}$ and $\mathrm{Fe}(\mathrm{II})$ at the surface of $\mathrm{Fe}_{2} \mathrm{O}_{3}$, therefore generating $\mathrm{SO}_{4}{ }^{\bullet-}$ and reforming $\mathrm{Fe}(\mathrm{III})$ (Equation (2)). $\mathrm{HO} \bullet$ also might have been formed by this reaction and contributed to pollutant degradation (Equations (3)-(5)) [35-37]. Therefore, the pollutant could be degraded by the generated surface-adsorbed radicals $\left(\mathrm{SO}_{4}{ }^{--}\right.$and $\left.\mathrm{HO}{ }^{\bullet}\right)$ that might diffuse into the aqueous solution (Equation (5)) [34].

Figure 5 shows the effect of two radical scavengers, ethanol (EtOH) and $t$-butanol (TBA), on the degradation of OTC. According to equations (Equations (6)-(9)) [38], the reaction rate of $\mathrm{EtOH}$ and $\mathrm{HO}^{\bullet}$ is 50 times faster than that of $\mathrm{EtOH}$ and $\mathrm{SO}_{4}{ }^{\bullet-}$, while TBA reacts with $\mathrm{HO}^{\bullet}$ almost 1000 times faster than that with $\mathrm{SO}_{4}{ }^{\bullet-}$. From the results, the oxidation of OTC was significantly reduced with the addition of TBA and $\mathrm{EtOH}$, suggesting that $\mathrm{EtOH}$ can effectively inhibit the oxidation efficiency. In addition, compared with $\mathrm{EtOH}$, the removal rate of OTC was found to be lower in the presence of TBA, which demonstrates that a small amount of $\mathrm{SO}_{4}{ }^{\bullet-}$ remaining in the solution can still decompose OTC. Thus, it can be concluded that $\mathrm{SO}_{4}{ }^{\bullet-}$ is the dominant oxidizing species in the OTC degradation process by persulfate activation using HWWC catalysts.

$$
\begin{gathered}
\mathrm{EtOH}+\mathrm{HO}^{\bullet} \rightarrow \text { Intermediates }\left(\mathrm{k}=(1.2-2.8) \times 10^{9} \mathrm{M}^{-1} \mathrm{~s}^{-1}\right) \\
\mathrm{EtOH}+\mathrm{SO}_{4}^{\bullet-} \rightarrow \text { Intermediates }\left(\mathrm{k}=(1.6-7.7) \times 10^{7} \mathrm{M}^{-1} \mathrm{~s}^{-1}\right) \\
\mathrm{TBA}+\mathrm{HO}^{\bullet} \rightarrow \text { Intermediates }\left(\mathrm{k}=(3.8-7.6) \times 10^{8} \mathrm{M}^{-1} \mathrm{~s}^{-1}\right) \\
\mathrm{TBA}+\mathrm{SO}_{4}^{\bullet-} \rightarrow \text { Intermediates }\left(\mathrm{k}=(4.0-9.1) \times 10^{5} \mathrm{M}^{-1} \mathrm{~s}^{-1}\right)
\end{gathered}
$$

\subsection{Effects of HWWC Dosage and PS Concentration on OTC Degradation}

The catalyst dosage and PS concentration are important factors in pollutant degradation. Therefore, degradation experiments with various HWWC dosages $(0.05,0.20$, and $0.40 \mathrm{~g} / \mathrm{L})$ and PS concentrations $(0.5,1.0$, and $2.0 \mathrm{mM}$ ) were investigated. As shown in Figure 6, the degradation efficiency of OTC increased in proportion to the HWWC dosage and PS concentration. The $k$ value increased from $0.02 \pm 0.00 \mathrm{~min}^{-1}$ to $0.14 \pm 0.02 \mathrm{~min}^{-1}$ and increased from $0.09 \pm 0.01 \mathrm{~min}^{-1}$ to $0.12 \pm 0.01 \mathrm{~min}^{-1}$ when the HWWC dosage 
and PS concentration increased, respectively. HWWC and PS were the activator and source of reactive radical species, respectively. Thus, their increase could promote OTC degradation [39].

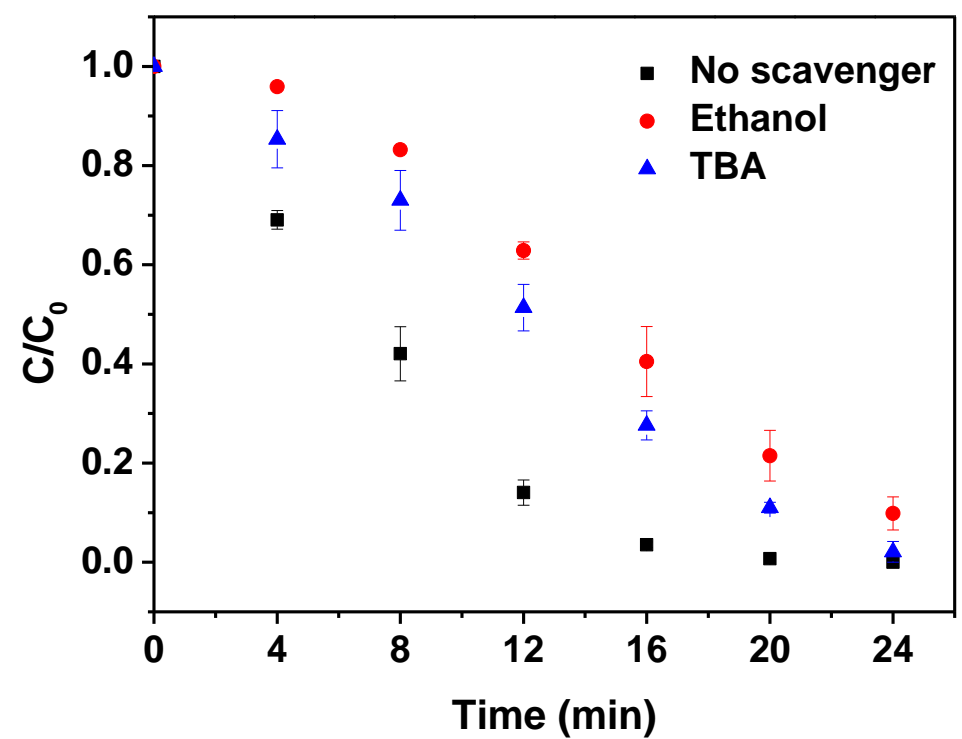

Figure 5. Oxytetracycline (OTC) degradation in the presence of scavengers ([OTC $]_{0}=20 \mu \mathrm{M}$, $\left.[\mathrm{PS}]_{0}=1 \mathrm{mM},[\mathrm{HWWC}]_{0}=0.2 \mathrm{~g} / \mathrm{L},[\text { scavenger }]_{0}=10 \mathrm{mg} / \mathrm{L}, \mathrm{pH}=6\right)$. PS: persulfate; HWWC: hand-warmer waste catalyst.
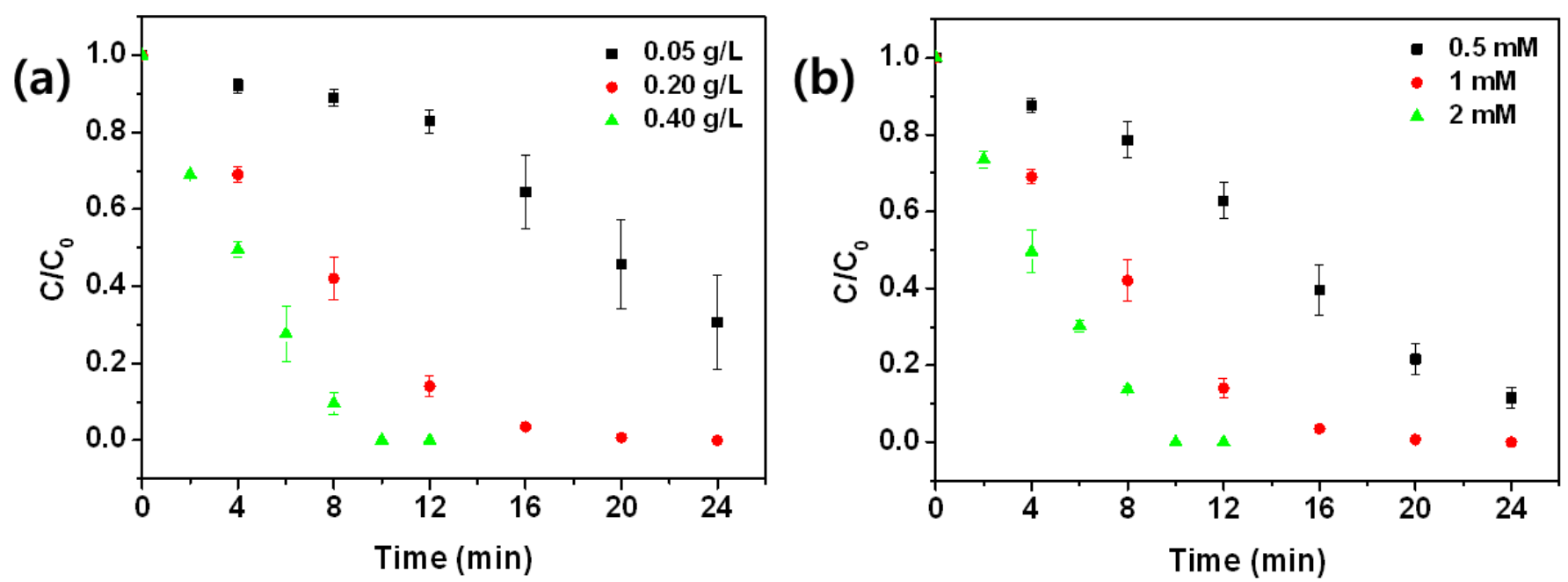

Figure 6. Oxytetracycline (OTC) degradation with (a) different catalyst dosages and (b) different persulfate concentrations $\left([\mathrm{OTC}]_{0}=20 \mu \mathrm{M}\right)$.

\subsection{Effects of $\mathrm{pH}$ on OTC Degradation}

In heterogeneous PS activation, the initial $\mathrm{pH}$ has a significant influence on the degradation of pollutants [40]. Therefore, the degradation efficiency at various solution $\mathrm{pH}$ conditions $(3,4,6$, and 8$)$ was investigated (Figure 7). As shown in Figure 5, the removal ratio of OTC at $4 \mathrm{~min}$ was $70.8 \pm 7.0 \%, 70.7 \pm 0.8 \%, 31.0 \pm 1.9 \%$, and $28.6 \pm 0.9 \%$ at a $\mathrm{pH}$ of $3,4,6$, and 8 , respectively. The degradation performance at a $\mathrm{pH}$ of 3 and 4 showed no significant change, but the efficiency significantly decreased when the solution $\mathrm{pH}$ increased from 4 to 8 , therefore implying that acidic conditions were more favorable for the degradation of OTC by heterogeneous PS activation. This result was observed because the surface properties of the catalyst and the lifetimes of the generated radical species changed 
as the solution $\mathrm{pH}$ changed. When the point of zero charge of the catalyst was higher than the solution $\mathrm{pH}$, the surface of the catalyst displayed a positive charge; thus, it could adsorb more $\mathrm{SO}_{4}{ }^{\bullet-}$ [41]. In addition, the lifetimes of $\mathrm{HO}^{\bullet}$ and $\mathrm{SO}_{4}{ }^{\bullet-}$ decreased under alkaline conditions; thus, the radical species that diffused into the bulk phase might have been insufficient for further degradation [42].

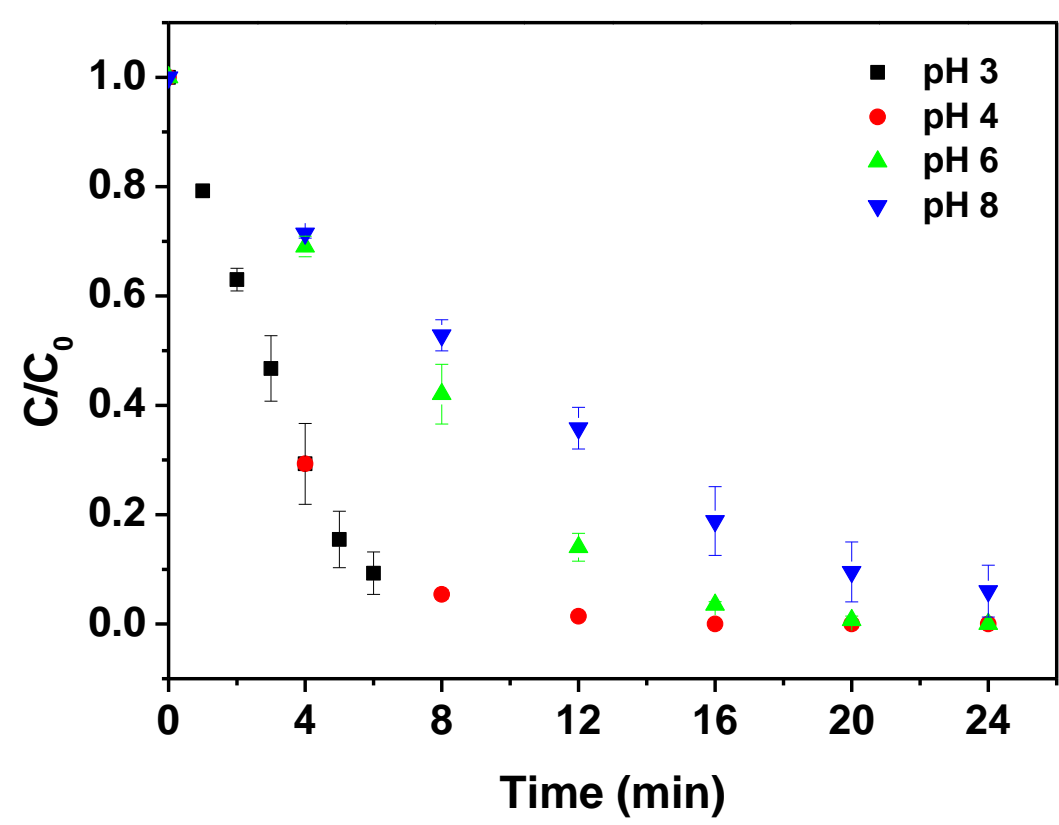

Figure 7. Oxytetracycline (OTC) degradation efficiency with different $\mathrm{pH}$ conditions $\left([\mathrm{PS}]_{0}=1 \mathrm{mM}\right.$, $\left.[\mathrm{OTC}]_{0}=20 \mu \mathrm{M},[\mathrm{HWWC}]_{0}=0.2 \mathrm{~g} / \mathrm{L}\right)$. PS: persulfate; HWWC: hand-warmer waste catalyst.

\subsection{Applicability of HWWC}

The stability of the catalyst is an important index for practical applications in wastewater treatment. Therefore, sequential OTC degradation experiments were performed to test the reusability of the catalyst (Figure 8a). The reaction was conducted for $24 \mathrm{~min}$, after which the HWWC was recovered using an external magnet. The degradation performance of the HWWC did not significantly decrease after eight repeat experiments with a final degradation efficiency of $92.7 \%$. This result indicated that the catalyst exhibited excellent regeneration performance and stability. Since the actual environmental water contains a large amount of organic and inorganic compounds, the activity of $\mathrm{SO}_{4}{ }^{\bullet-}$ and $\mathrm{HO}^{\bullet}$ may be reduced. Therefore, it is necessary to investigate the effect of radical scavengers of these organic and inorganic compounds. Chloride ion $\left(\mathrm{Cl}^{-}\right)$, one of the representative inorganic compounds present in large amounts in environmental water, can reduce degradation efficiency by the following equations (Equations (10)-(11)) [38,43]. In the present condition, however, the effect of chloride ion $\left(\left[\mathrm{Cl}^{-}\right]_{0}=10 \mathrm{mg} / \mathrm{L}\right.$ ) was negligible (Figure $8 \mathrm{~b}$ ). By contrast, the OTC degradation was significantly reduced by the organic compounds present in the secondary effluent $\left(\mathrm{pH}=7.2,[\mathrm{DOC}]_{0}=4.71 \mathrm{mg} / \mathrm{L}, \mathrm{UV}_{254}=0.100, \mathrm{SUVA}=2.12\right)$ (Figure 8c). This is because the electron-rich moieties in the molecular structure of natural organic matter (NOM) present in the secondary effluent can be readily attacked by electrophilic radicals such as $\mathrm{SO}_{4}{ }^{\bullet-}$ and $\mathrm{HO}{ }^{\bullet}$ [44].

$$
\begin{gathered}
\mathrm{SO}_{4}{ }^{\bullet-}+\mathrm{Cl}^{-} \rightarrow \mathrm{SO}_{4}{ }^{2-}+\mathrm{Cl}^{\bullet} \\
\mathrm{Cl}^{-}+\mathrm{HO}^{\bullet} \rightarrow \mathrm{Cl}^{\bullet}+\mathrm{HO}^{-}
\end{gathered}
$$



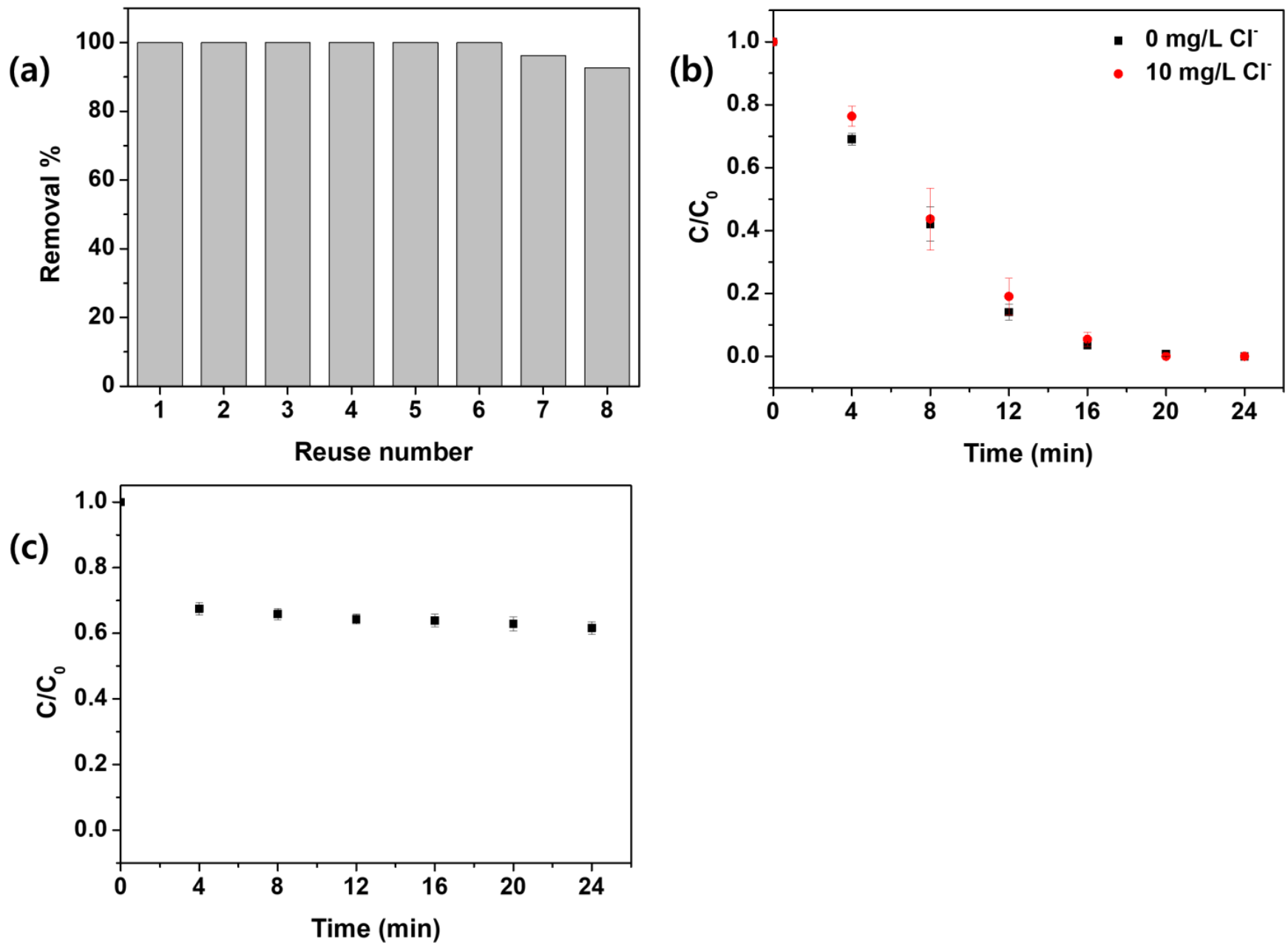

Figure 8. (a) Sequential oxytetracycline (OTC) degradation test $\left([\mathrm{PS}]_{0}=1 \mathrm{mM}\right.$, $[\mathrm{OTC}]_{0}=20 \mu \mathrm{M},[\mathrm{HWWC}]_{0}=0.2 \mathrm{~g} / \mathrm{L}$, $\mathrm{pH}=6)$; (b) OTC degradation in the presence of $\mathrm{Cl}^{-}\left(\left[\mathrm{Cl}^{-}\right]_{0}=10 \mathrm{mg} / \mathrm{L}\right)$; (c) Degradation kinetics of OTC by persulfate activation using HWWC in the secondary effluent $\left(\mathrm{pH}=7.2,[\mathrm{DOC}]_{0}=4.71 \mathrm{mg} / \mathrm{L}, \mathrm{UV}_{254}=0.100, \mathrm{SUVA}=2.12\right)$. PS: persulfate; HWWC: hand-warmer waste catalyst.

\section{Conclusions}

HWWC was successfully prepared by a simple magnetic separation method. The XRD and SEM-EDS results revealed that the HWWC consisted of a mixture of $\gamma-\mathrm{Fe}_{2} \mathrm{O}_{3}$ and $\alpha-\mathrm{Fe}_{2} \mathrm{O}_{3}$. The magnetic saturation of HWWC was sufficient to be separated by conventional magnets, which can facilitate their application for water treatment. The control experiment showed that OTC was removed by the generated radical species when both HWWC and PS were present. $\mathrm{SO}_{4}{ }^{\bullet-}$ was the dominant oxidizing species in the OTC degradation by persulfate activation using HWWC catalyst. Influencing parameters such as HWWC dose, PS concentration, and solution $\mathrm{pH}$ were evaluated, and the degradation efficiency of OTC increased with increasing HWWC dose and PS concentration, and the optimal $\mathrm{pH}$ values for OTC degradation were 3 and 4. In addition, the HWWC degraded OTC after eight repeat experiments with great stability. Degradation efficiency was significantly affected by NOM present in the secondary effluent, while the effect of chloride ions was negligible. Overall, these results suggest that PS activation using magnetic $\mathrm{Fe}_{2} \mathrm{O}_{3}$ catalysts derived from hand-warmer waste could be an effective alternative for removing OTC and other recalcitrant organic compounds in water. 
Author Contributions: Conceptualization, Y.-J.L. and C.-G.L.; methodology, Y.-J.L.; validation, Y.-J.L.; formal analysis, Y.-J.L.; writing-original draft preparation, Y.-J.L.; writing-review and editing, C.-G.L., S.-J.P. and E.H.J.; visualization, Y.-J.L.; supervision, C.-G.L., S.-J.P. and E.H.J.; funding acquisition, E.H.J. All authors have read and agreed to the published version of the manuscript.

Funding: This work was conducted with the support of the Cooperative Research Program for Agriculture Science and Technology Development (Project No. PJ01571602), Rural Development Administration, Korea.

Institutional Review Board Statement: Not applicable.

Informed Consent Statement: Not applicable.

Conflicts of Interest: The authors declare no conflict of interest.

\section{References}

1. Liu, D.; Li, M.; Li, X.; Ren, F.; Sun, P.; Zhou, L. Core-shell Zn/Co MOFs derived Co3O4/CNTs as an efficient magnetic heterogeneous catalyst for persulfate activation and oxytetracycline degradation. Chem. Eng. J. 2020, 387, 124008. [CrossRef]

2. Baquero, F.; Martinez, J.L.; Canton, R. Antibiotics and antibiotic resistance in water environments. Curr. Opin Biotechnol. 2008, 19, 260-265. [CrossRef]

3. Wang, L.; Yang, H.; Zhang, C.; Mo, Y.; Lu, X. Determination of oxytetracycline, tetracycline and chloramphenicol antibiotics in animal feeds using subcritical water extraction and high performance liquid chromatography. Anal. Chim. Acta 2008, 619, 54-58. [CrossRef]

4. Uslu, M.O.; Balcioglu, I.A. Simultaneous removal of oxytetracycline and sulfamethazine antibacterials from animal waste by chemical oxidation processes. J. Agric. Food Chem. 2009, 57, 11284-11291. [CrossRef] [PubMed]

5. Liu, Y.; He, X.; Fu, Y.; Dionysiou, D.D. Kinetics and mechanism investigation on the destruction of oxytetracycline by UV-254nm activation of persulfate. J. Hazard. Mater. 2016, 305, 229-239. [CrossRef]

6. Kemper, N. Veterinary antibiotics in the aquatic and terrestrial environment. Ecol. Indic. 2008, 8, 1-13. [CrossRef]

7. Sarmah, A.K.; Meyer, M.T.; Boxall, A.B. A global perspective on the use, sales, exposure pathways, occurrence, fate and effects of veterinary antibiotics (VAs) in the environment. Chemosphere 2006, 65, 725-759. [CrossRef]

8. Kummerer, K. Antibiotics in the aquatic environment-A review-Part I. Chemosphere 2009, 75, 417-434. [CrossRef]

9. Zheng, S.; Qiu, X.; Chen, B.; Yu, X.; Liu, Z.; Zhong, G.; Li, H.; Chen, M.; Sun, G.; Huang, H.; et al. Antibiotics pollution in Jiulong River estuary: Source, distribution and bacterial resistance. Chemosphere 2011, 84, 1677-1685. [CrossRef]

10. Li, B.; Zhang, T. Mass flows and removal of antibiotics in two municipal wastewater treatment plants. Chemosphere 2011, 83, 1284-1289. [CrossRef]

11. Li, W.; Shi, Y.; Gao, L.; Liu, J.; Cai, Y. Occurrence and removal of antibiotics in a municipal wastewater reclamation plant in Beijing, China. Chemosphere 2013, 92, 435-444. [CrossRef]

12. Xu, J.; Xu, Y.; Wang, H.; Guo, C.; Qiu, H.; He, Y.; Zhang, Y.; Li, X.; Meng, W. Occurrence of antibiotics and antibiotic resistance genes in a sewage treatment plant and its effluent-receiving river. Chemosphere 2015, 119, 1379-1385. [CrossRef]

13. Golovko, O.; Kumar, V.; Fedorova, G.; Randak, T.; Grabic, R. Seasonal changes in antibiotics, antidepressants/psychiatric drugs, antihistamines and lipid regulators in a wastewater treatment plant. Chemosphere 2014, 111, 418-426. [CrossRef]

14. Chen, J.; Hu, Y.; Huang, W.; Liu, Y.; Tang, M.; Zhang, L.; Sun, J. Biodegradation of oxytetracycline and electricity generation in microbial fuel cell with in situ dual graphene modified bioelectrode. Bioresour. Technol. 2018, 270, 482-488. [CrossRef]

15. Garrido-Ramírez, E.G.; Theng, B.K.G.; Mora, M.L. Clays and oxide minerals as catalysts and nanocatalysts in Fenton-like reactions-A review. Appl. Clay Sci. 2010, 47, 182-192. [CrossRef]

16. Feng, Y.; Wu, D.; Liao, C.; Deng, Y.; Zhang, T.; Shih, K. Red mud powders as low-cost and efficient catalysts for persulfate activation: Pathways and reusability of mineralizing sulfadiazine. Sep. Purif. Technol. 2016, 167, 136-145. [CrossRef]

17. Liang, C.J.; Bruell, C.J.; Marley, M.C.; Sperry, K.L. Thermally Activated Persulfate Oxidation of Trichloroethylene (TCE) and 1,1,1-Trichloroethane (TCA) in Aqueous Systems and Soil Slurries. Soil Sediment Contam. Int. J. 2010, 12, 207-228. [CrossRef]

18. Zhang, T.; Chen, Y.; Wang, Y.; Le Roux, J.; Yang, Y.; Croue, J.P. Efficient peroxydisulfate activation process not relying on sulfate radical generation for water pollutant degradation. Environ. Sci. Technol. 2014, 48, 5868-5875. [CrossRef] [PubMed]

19. Abu Amr, S.S.; Aziz, H.A.; Adlan, M.N. Optimization of stabilized leachate treatment using ozone/persulfate in the advanced oxidation process. Waste Manag. 2013, 33, 1434-1441. [CrossRef]

20. Peng, L.; Deng, D.; Guan, M.; Fang, X.; Zhu, Q. Remediation HCHs POPs-contaminated soil by activated persulfate technologies: Feasibility, impact of activation methods and mechanistic implications. Sep. Purif. Technol. 2015, 150, 215-222. [CrossRef]

21. Liu, C.S.; Shih, K.; Sun, C.X.; Wang, F. Oxidative degradation of propachlor by ferrous and copper ion activated persulfate. Sci. Total Environ. 2012, 416, 507-512. [CrossRef]

22. Teel, A.L.; Ahmad, M.; Watts, R.J. Persulfate activation by naturally occurring trace minerals. J. Hazard. Mater. 2011, 196, 153-159. [CrossRef]

23. Fang, G.-D.; Dionysiou, D.D.; Al-Abed, S.R.; Zhou, D.-M. Superoxide radical driving the activation of persulfate by magnetite nanoparticles: Implications for the degradation of PCBs. Appl. Catal. B: Environ. 2013, 129, 325-332. [CrossRef] 
24. Ioannidi, A.; Oulego, P.; Collado, S.; Petala, A.; Arniella, V.; Frontistis, Z.; Angelopoulos, G.N.; Diaz, M.; Mantzavinos, D. Persulfate activation by modified red mud for the oxidation of antibiotic sulfamethoxazole in water. J. Environ. Manag. 2020 270, 110820. [CrossRef] [PubMed]

25. Naim, S.; Ghauch, A. Ranitidine abatement in chemically activated persulfate systems: Assessment of industrial iron waste for sustainable applications. Chem. Eng. J. 2016, 288, 276-288. [CrossRef]

26. Lian, J.-Z.; Tsai, C.-T.; Chang, S.-H.; Lin, N.-H.; Hsieh, Y.-H. Iron waste as an effective depend on TiO2 for photocatalytic degradation of dye waste water. Optik 2017, 140, 197-204. [CrossRef]

27. Yu, Y.; Paul Chen, J. Key factors for optimum performance in phosphate removal from contaminated water by a Fe-Mg-La tri-metal composite sorbent. J. Colloid. Interface Sci. 2015, 445, 303-311. [CrossRef]

28. Qiu, J.; Yang, R.; Li, M.; Jiang, N. Preparation and characterization of porous ultrafine Fe2O3 particles. Mater. Res. Bull. 2005, 40, 1968-1975. [CrossRef]

29. Molodtsova, T.; Gorshenkov, M.; Saliev, A.; Vanyushin, V.; Goncharov, I.; Smirnova, N. One-step synthesis of $\gamma$-Fe2O3/Fe3O4 nanocomposite for sensitive electrochemical detection of hydrogen peroxide. Electrochim. Acta 2021, 370, 137723. [CrossRef]

30. Khoshnam, M.; Salimijazi, H. Synthesis and characterization of magnetic-photocatalytic Fe3O4/SiO2/a-Fe2O3 nano core-shell. Surf. Interfaces 2021, 26, 101322. [CrossRef]

31. Chu, J.-H.; Kang, J.-K.; Park, S.-J.; Lee, C.-G. Application of magnetic biochar derived from food waste in heterogeneous sono-Fenton-like process for removal of organic dyes from aqueous solution. J. Water Process Eng. 2020, 37, 101455. [CrossRef]

32. Chu, J.-H.; Kang, J.-K.; Park, S.-J.; Lee, C.-G. Enhanced sonocatalytic degradation of bisphenol A with a magnetically recoverable biochar composite using rice husk and rice bran as substrate. J. Environ. Chem. Eng. 2021, 9, 105284. [CrossRef]

33. Zouanti, M.; Bezzina, M.; Dhib, R. Experimental study of degradation and biodegradability of oxytetracycline antibiotic in aqueous solution using Fenton process. Environ. Eng. Res. 2019, 25, 316-323. [CrossRef]

34. Ma, Q.; Zhang, X.; Guo, R.; Zhang, H.; Cheng, Q.; Xie, M.; Cheng, X. Persulfate activation by magnetic $\gamma$-Fe2O3/Mn3O4 nanocomposites for degradation of organic pollutants. Sep. Purif. Technol. 2019, 210, 335-342. [CrossRef]

35. Guan, Y.H.; Ma, J.; Ren, Y.M.; Liu, Y.L.; Xiao, J.Y.; Lin, L.Q.; Zhang, C. Efficient degradation of atrazine by magnetic porous copper ferrite catalyzed peroxymonosulfate oxidation via the formation of hydroxyl and sulfate radicals. Water Res. 2013, 47, 5431-5438. [CrossRef]

36. Pham, A.N.; Xing, G.; Miller, C.J.; Waite, T.D. Fenton-like copper redox chemistry revisited: Hydrogen peroxide and superoxide mediation of copper-catalyzed oxidant production. J. Catal. 2013, 301, 54-64. [CrossRef]

37. Liang, H.-Y.; Zhang, Y.-Q.; Huang, S.-B.; Hussain, I. Oxidative degradation of p-chloroaniline by copper oxidate activated persulfate. Chem. Eng. J. 2013, 218, 384-391. [CrossRef]

38. Norzaee, S.; Taghavi, M.; Djahed, B.; Kord Mostafapour, F. Degradation of Penicillin G by heat activated persulfate in aqueous solution. J. Environ. Manag. 2018, 215, 316-323. [CrossRef]

39. Liang, C.; Lee, I.L. In situ iron activated persulfate oxidative fluid sparging treatment of TCE contamination-a proof of concept study. J. Contam. Hydrol. 2008, 100, 91-100. [CrossRef]

40. Chen, Y.; Yan, J.; Ouyang, D.; Qian, L.; Han, L.; Chen, M. Heterogeneously catalyzed persulfate by CuMgFe layered double oxide for the degradation of phenol. Appl. Catal. A: Gen. 2017, 538, 19-26. [CrossRef]

41. Long, M.; Brame, J.; Qin, F.; Bao, J.; Li, Q.; Alvarez, P.J. Phosphate Changes Effect of Humic Acids on TiO2 Photocatalysis: From Inhibition to Mitigation of Electron-Hole Recombination. Environ. Sci. Technol. 2017, 51, 514-521. [CrossRef] [PubMed]

42. Li, Z.; Chen, Z.; Xiang, Y.; Ling, L.; Fang, J.; Shang, C.; Dionysiou, D.D. Bromate formation in bromide-containing water through the cobalt-mediated activation of peroxymonosulfate. Water Res. 2015, 83, 132-140. [CrossRef] [PubMed]

43. Chu, J.-H.; Kang, J.-K.; Park, S.-J.; Lee, C.-G. Ultrasound-activated peroxydisulfate process with copper film to remove bisphenol A: Operational parameter impact and back propagation-artificial neural network modeling. J. Water Process Eng. 2021, $44,102326$. [CrossRef]

44. Ma, J.; Yang, Y.; Jiang, X.; Xie, Z.; Li, X.; Chen, C.; Chen, H. Impacts of inorganic anions and natural organic matter on thermally activated persulfate oxidation of BTEX in water. Chemosphere 2018, 190, 296-306. [CrossRef] 